\title{
A Comprehensive 21st Century Child Development through Scientific Process in Early Science
}

\author{
Rohani Husaini, Zanaton Ikhsan, Hasnah Toran \\ Faculty of Education, Universiti Kebangsaan Malaysia, Bangi, Malaysia \\ Email: rohanihusaini@gmail.com
}

How to cite this paper: Husaini, R., Ikhsan, Z., \& Toran, H. (2019). A Comprehensive 21st Century Child Development through Scientific Process in Early Science. Creative Education, 10, 2784-2795. https://doi.org/10.4236/ce.2019.1012205

Received: October 21, 2019

Accepted: November 25, 2019

Published: November 28, 2019

Copyright $\odot 2019$ by author(s) and Scientific Research Publishing Inc. This work is licensed under the Creative Commons Attribution International License (CC BY 4.0).

http://creativecommons.org/licenses/by/4.0/

\section{c) (i) Open Access}

\begin{abstract}
The purpose of this study is to explore and identify the practice of applying science processes in early childhood teaching by preschool teachers with a focus on approach, interaction and environmental management. This study uses a descriptive qualitative approach. It involves 5 preschool teachers from different preschools. Teacher selection based on excellence and active involvement of preschool teacher. To be more precise, this study is referred to as a multidisciplinary study. Data collection is through interviews and is supported by document observation and analysis. Data were analyzed using Atlas. Ti 7 software to generate themes. The finding of the study concludes that the effectiveness of early science learning depends on children's mastery of science process skill. Therefore, teacher pedagogical knowledge is very important. This study is able to provide guidance on the application of science processes in early science teaching with a focus on environmental management and can be used by preschool teachers in early science teaching.
\end{abstract}

\section{Keywords}

Process of Science, Constructivism, Exploration, Approach, Creativity

\section{Introduction}

Science-based societies will value science as a landmark for achievement in human civilization. Lilia (2013) mastery of science literacy is a lifelong learning tool to provide people with the ability to cope with and experience life full of impact in the future. In this regard, the government has announced the educational reform of the Education Development Plan 2013-2025 which provides a comprehensive development framework to bring about a rapid and sustainable 
transformation of the education system by 2025. 21st Century education demands that education in this country move in tandem with developed countries the other in the face of the industrial revolution era 4.0 Amirah Abdol Rahaman (2018). In the pursuit of this goal, the Ministry of Education Malaysia has emphasized that focus should be given to science subjects and this should start with Early Science education. Providing strong, consistent and objective early childhood education will succeed in shaping future generations. Vyogtsky (1984) states that early education of science should begin at an early stage. Piaget (1970) argues that all humans are born with the ability to assimilate and accommodate. This situation affects children whose nature is constantly associated with their surrounding phenomena. Bruner (1966) argues that childhood is the dominant stage in the context of constructing ideas and actively transforming information.

The study of Zurida \& Hashimah (2004) concluded that science education requires children to learn through knowledge. Children explore the environment through exploration. Children use science process strategies such as observing, classifying, measuring, communicating, inferring, predicting and predicting to test their ideas. Science introduces the world to children. A meaningful and quality Early Science teaching experience for preschool children can have a long-term impact on children's mastery and achievement in early Science teaching. The question is how well does the education system produce the generation that it wants? Are preschool teachers able and able to teach science process skills in teaching and learning in the classroom? Does the learning environment stimulate early Science teaching and engage the children in learning? Lilia (2013) emphasizes that two core elements of science education need to be effectively addressed-the quality of the science teachers produced and their professionalism. The factors of teaching practice and educational learning are very important to ensure effective teaching and learning.

\section{Background Study}

\subsection{Transformation of Preschool Education Curriculum}

The Ministry of Education Malaysia has implemented the transformation of preschool education curriculum since 2010. The process of transformation of preschool education curriculum involves restructuring and improvement of design, organization, pedagogy, curriculum reaffirmation, time allocation and curriculum management (Curriculum Development Division, 2010). Curriculum transformations are undertaken to provide students with the knowledge, skills and values relevant to current and future needs. Scientific skills in the process of science require that teachers and children constantly explore and investigate for information and solve problems. As such, making the transformation process as a teacher platform is always ready with a variety of teaching strategies that can challenge students' minds.

\subsection{Early Science in the National Preschool Standard Curriculum}

The National Preschool Standard Curriculum (2010) outlines the early science 
contained in the Science and Technology Curriculum, which is a must-teach course in preschool. The main objectives of early science activities are for children to conduct simple investigations with guidance, practice science process skills, practice reasoning and exploration as well as enhance curiosity. The focus areas are scientific attitudes, scientific skills, nature investigations, material investigations and physical investigations. Early introduction with a focus on scientific attitudes and scientific skills clearly indicates that the main goals of the curriculum are aimed at the early development of children's interest in science. This is important and in line with the Ministry of Education's goal in the National Education Policy (2012) to make science and technology an important medium for developing 21 st century skills. Children with the environment. This is emphasized in the National Education Policy (2012) for 21st century skills. In the course of this exploration, positive scientific attitudes such as curiosity, systematic and thoroughness will be formed. Basic science-based skills such as observing skills, measuring using non-standard units, comparing and classifying will also be developed. Exploration is carried out on the natural world (examples: plants, animals), the nature of matter (examples: sunken and rising objects, water, magnets) and the physical realm (examples: rainbow, weather). This pillar is more about mastery of skills than knowledge acquisition. Teachers need to be open to the views and insights of student exploration.

\subsection{Teacher Teaching Practice}

The effectiveness of teacher teaching practices is strongly influenced by the knowledge, skills and competencies of teachers in formulating and managing teaching strategies. Teacher competencies and skills in planning before, during and after a teaching and learning are at the heart of effective teaching and learning processes in the classroom. The National Association for the Education of Young Children (NAEYC) has always emphasized that teaching and learning practices in early childhood education should be appropriate to children's development as needed and appropriate to their development.

(Malaysian Education Development Plan Report, 2013-2025) To produce quality students needs to source quality teachers in delivering effective early childhood science teaching effectively and effectively. Lilia (2013) argues that Science and technology are a driving force behind the development of innovative society and greatly impact economic development. This illustration clearly shows the importance of effective teacher teaching in science education as it has a great impact on the context of education or community development as a whole. In this regard, the implementation of the National Preschool Standard Curriculum (2010) emphasizes a stimulating approach towards mastering the science process skills. Teacher teaching is more focused on student-centered, inquiry-based, learning through play, project approaches, thematic approaches and integrated approaches. The application of science process skills can be implemented through the approach described. Early Introduction to Science in Science and Technology supports children to explore their environment using sensory organs and 
simple equipment. In the course of this exploration, positive scientific attitudes such as curiosity, systematic and thoroughness can be formed. Basic science process skills such as observing, measuring, comparing and classifying skills will also be applied to preschool children.

Lilia (2013) states that teachers directly contribute to the formation of misconceptions in their learning. This means that it is interesting or otherwise teaching, depending on the role of the teacher. Educators play a very important role in transforming students' perceptions of science and technology as an interesting and worthwhile science. The importance of these early experiences and learning leads to the need to pay special attention to the quality of preschool programs (National Research Council, 2001). This is because high quality preschool programs have a significant impact on holistic development of children (Barnett, 2004). Therefore, the role of teachers as educators is crucial to changing the perception that science is difficult and unattractive. Meaningful and engaging teaching has a positive impact on children's learning. The question is how can teachers implement early science teaching and learning and fun situations?

Teachers' understanding of early science teaching differs from the quality of early science teaching. The findings of the study show that teachers in Malaysia still lack the ability to meet the characteristics of quality teachers especially in teaching Science (Subahan, Meerah, Lilia, \& Thiagarajan, 2010). The results show that the level of knowledge of teachers in the field of science is very low. Knowledge transfer is minimal. Problems stem from teachers' weaknesses in knowledge and knowledge related to science. If teachers do not have the knowledge, skills or commitment to the knowledge they want to teach, it can make it difficult for students to master knowledge of environmental education (Wilke, 1985; Sharifah et al., 2012).

Studies (Chiam, 2003; Zurida \& Hashimah, 2004) also argue that some of the reasons why preschool teachers fail to effectively teach are because preschool teachers do not understand teaching and learning concepts that are relevant to children's development. They teach the subjects separately in a very formal form as they do in primary schools. This situation can make teaching unattractive and fail to actively engage children.

The string of misunderstandings in teaching has led to the issue of teachers' attitude towards teaching in Science Education. The findings of the study by $\mathrm{Zu}$ rida \& Hashimah (2004) also show that teachers are not only less knowledgeable in content but also less confident in teaching science. The findings of the study (Wilke, 1985; Sharifah et al., 2012) found that the source of effective teachers in teaching is that effective teaching and learning depends on the effectiveness of teacher presentation in the classroom. This finding is in line with the findings of a study by (Cobern \& Loving, 2002: Ward \& Mc Cotter, 2004) stating that teachers 'attitudes, lack of confidence and not making reflective thinking practices in teaching and learning a factor in teachers' failure to achieve their teach- 
ing objectives.

These studies clearly show that preschool teachers have problems in teaching early science. They were not only unsure of their teaching ability but also unsure of how to teach science concepts and were unsure of what science to convey. These issues need to be addressed to make teachers more proficient and effective in teaching Early Science education.

Based on the description of the problem statement, it is clear that the quality of teachers in Early Science teaching needs to be improved. Issues of weaknesses related to mastery of science concept skills, lack of teaching content knowledge and teaching pedagogy need to be addressed to ensure that Science teaching is more meaningful. The moral and spiritual improvement of teachers in Science Early education also needs to be taken into account for improving teachers' confidence in teaching. Educators are the catalyst for the pursuit of human capital. This study aims to identify the practice of teaching science process skills in early science teaching by preschool teachers in the context of implementing appropriate activities for teaching early science. Scientific skills in the context of this study are the basic skills of the scientific process namely observation, classification, measurement, inference, prediction and expectation and communication.

\section{Concept and Theory of Relationship with Early Science}

\section{Teaching and Learning Science from Constructivism Perspectives}

Zurida (2007) contraceptive theory emphasizes the role of the individual, the importance of building meaning and the active role of the student. Learning from the perspective of contraception is seen as a process by which students actively build meaning from the experiences they experience and relate to existing knowledge and social contexts. In theory, children are active and they build knowledge through engagement and interaction with the environment. Observation of children will change the way children think. Children are defined as young scientists. They watch, explore, love experiments and do it. But the way children think at this level varies. The maturity of children's thinking is increasing with age.

Self-contradiction recognizes that children's learning takes place with the guidance of teachers, adults, or peers. Learning focuses more on the role of teachers as educators and educators in the development of children's knowledge (Piaget; 1970; Santrock, 2011). Contraceptive learning encourages children to discover and explore. Santrock (2011), Social constructivism by Vygostky (1978) emphasizes the role of scaffolding in children's learning. In line with the study by Hafizah et al. (2019) which emphasized that the socio-emotional aspect plays an important role in developing children's perception of the environment, and determines the adaptation process. Socio-motive development is the development of maturity and learning. The level of achievement and maturity of children depends on the guidance and guidance given by the adults around them. 
From the perspective of constructivism, students cannot be passive in accepting the knowledge provided by teachers. Teachers also do not have to be the presenter or the conductor of knowledge and manage the class. From the perspective of constructivism, learning is the process of gaining knowledge, and this process is complex and active as a result of the interaction of cognitive processes. This process also involves active interactions between teachers and students. Students will try to build on the meaning of their learning by linking it with existing knowledge and past experience.

Brooks and Brooks (2001) outline five key principles in constructivist learning. The first lesson should start with giving students relevant problems. The topics discussed should be of interest to students. This can be done through demonstrations, interesting activities or challenging issues. One of the features of a challenging problem is that students need to make predictions that can be tested. Challenging problems also do not require sophisticated, costly apparatus to conduct an experiment. The level of difficulty chosen enables a variety of approaches to be used to achieve solutions and activities that encourage teamwork.

The second principle is that the activities and problems should be based on the science concepts to be learned. This way students better understand the concepts presented through the context of the problem they want to solve. This approach will also make learning more relevant and meaningful to students. Third, teachers also need to provide space and opportunities for students to present their ideas and ideas regarding the phenomenon being studied.

Fourth, after drawing on students' initial ideas, teachers need to tailor their teaching to their thinking. In the process of teaching and learning, assessing student progress is important and necessary. In this context, teachers need to interpret student learning in the context of teaching.

A study by Romarzila et al. (2018) found that project approaches are an appropriate approach for mastering science process skills. The goal of science is to provide children with the skills of the science process through scientific inquiry and children's thinking. The project approach engages students in hands-on, mind-on investigation activities through which students need to find solutions to problems. Through this project children learn how to forge, collaborate and appreciate a wide range of ideas. Some examples of project activities include finding information, making and recording observations, drawing, drawing and puppet making. Discuss, present ideas, ideas or explanations related to the phenomenon under study, interpret data, propose follow-up experiments and build hypotheses. Fifth, teachers are also encouraged to develop challenging questions and test students' thinking at a high cognitive level to stimulate learning.

\section{Methodology}

This study uses a descriptive qualitative approach. It involves 5 preschool teachers from different preschools. Teacher selection based on excellence and active involvement of preschool teacher. To be more precise this study is referred to as 
multiple case study. The first phase of this study was to use three methods of data collection, namely interview method as primary data. While the method of observation of the study sample and document analysis method to support interview data. Field notes and diaries are used to reinforce these three data. This phase will cover the teaching practices of science processes in the teaching of early science that include environmental factors, approach planning and teaching activities, materials. Researchers also use continuous records as an observation tool during teacher teaching.

The second phase is to analyze the data descriptively to produce findings that are then used to form a parallel pattern which then generates a model of the practice of applying the science process in early science teaching. The study involved six national school locations in Selangor and Putrajaya pre-schools. School selection is based on the recommendation of the department of education on the basis of excellence and active involvement of selected preschool teachers.

\section{Finding}

The findings of this study are aimed at exploring early science teaching activities that describe how science process skills are implemented in such teaching and thus formulate an effective science teaching skills teaching practice. Researchers formulate themes from the findings to facilitate better structured data management. Figure 1 is the theme of data management for this study.

\subsection{Knowledge}

Interviews and observations demonstrate that teachers' knowledge of the natural attitude of children with high curiosity and exploration affords teachers the opportunity to be more creative and to relate activities with hands-on science process skills. Hands-on activities prove to be effective as children go through phases of exploring, experimenting and experiencing their own effects and consequences. In line with the study of Mazlini Adnan et al. (2016) stated that children need to engage in activities to understand a science concept. Hands on is an element of learning $3 \mathrm{E}$ (explore, experience, experiments) which is the approach proposed in the PERMATA (2010) curriculum.

The findings show that teachers who master the content of the curriculum greatly influence the effectiveness of teaching, especially in terms of teaching techniques. Accurate, timely and proven instruction can show children learning outcomes in terms of science process skills such as observing, comparing, measuring, communicating and science process skills. It is important that preschool teachers understand the requirements that need to be provided in teaching through curriculum-based learning that provides opportunities for students to understand and carry out each teacher's teaching activities (Bredekamp \& Copple, 1997).

Active participation is very effective in group activities. The findings from the study show that the percentage of active communication occurs in group 


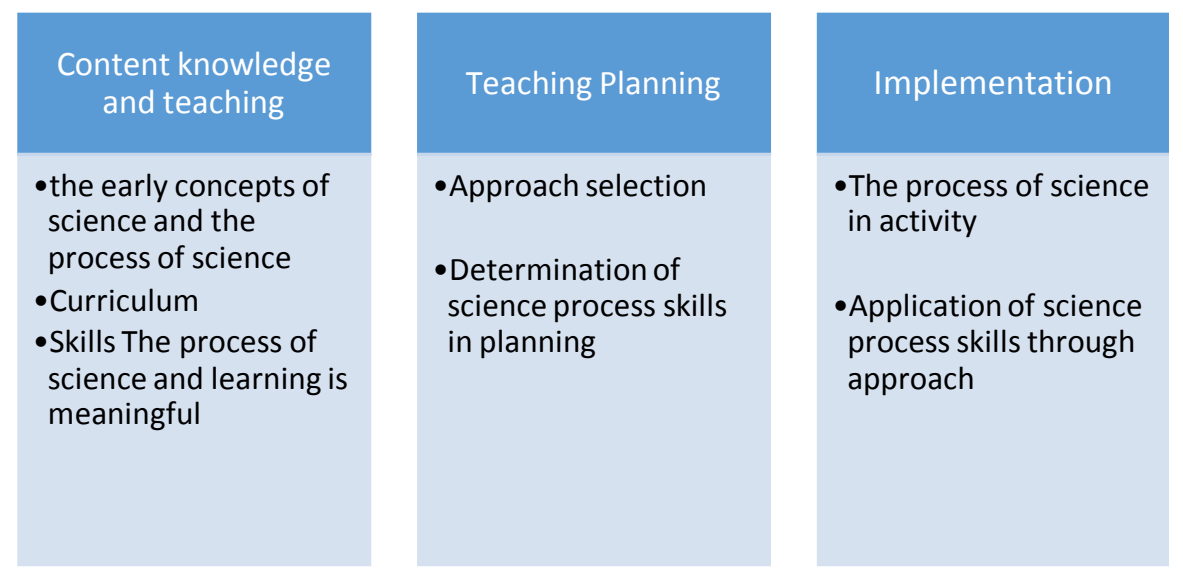

Figure 1. Themes of the findings of the application science process skills in activities.

activities. This means that teachers' planning of activities is very important and it is proven that implementing science processes is very effective in group activities. Communication becomes active when children guide one another when assigned tasks In line with studies by (Darling-Hammond, Lord McFarland, 2010; Baratz-Snowden, 2005; Romazila et al., 2018) that emphasize the importance of teachers understanding the process and selecting techniques and appropriate activities for the skills to be applied successfully.

\subsection{Teaching Planning}

Daily lesson plans show that the study participants understood the concept of teaching in accordance with the principles of difficulty leveling. The setting of learning objectives for early science is clear and in line with content and learning standards. However, teachers' ability to set science-based skills in teaching activities is minimal. Science process skills are not the main focus of teaching and very little in the integration. This practice makes transferring learning within the context of science process skills very limited. Writing routines focus only on content standards and learning standards, activities and general notes. There is no specific room for mastery of science process skills and this greatly influences the course of the lesson as it is the practice of the teacher to teach according to the planning notes. Activity planning documentation needs to be clear and instructive during the lesson. This finding is consistent with (Darling-Hammond \& Baratz-Snowden, 2005; Chong \& Cheah, 2009; Wong et al., 2008) that good planning demonstrates knowledge mastery The importance of mastering the content of the curriculum is a key factor in the successful transfer of knowledge and skills in teaching and learning.

\subsection{Implementation}

Science process skills do not just apply to teaching early science. Daily routines provide many opportunities for children to practice science process skills (Morrison, 2012). Integration occurs when the elements of science process skills are 
practiced according to the same principles but with different learning content. Science process skills across all stages according to the appropriateness of teaching activities. In line with Stivers \& Schudel's (2008) study of the integration of science processes in art, it was found that the process of science was very easy to integrate into all arts skills such as performing and visual, music, movement and dance.

Self-reflection practices make it easier for children to recall and re-practice the skills they have learned. There will be improvements to the skills that have been developed for the next activity. Creativity of teachers is important for improving children's understanding of the concept of science process skills. In line with studies by (Torrance, 1979; Ali, 2014) who agree that education is responsible for teaching students how to think and not to think.

The flow of ideas from different sources can create a diverse network of activities as well as more effective and meaningful teaching and learning. The findings show that co-teaching with peers either from the same option or from a current mainstream teacher who teaches science but not preschool option can create a very effective mentor activity. Likewise, parenting activities can provide a wide range of activity ideas. Ideas from parents are very helpful because parents are from a variety of backgrounds. Parental support and the provision of appropriate learning materials can enhance students' own learning ability.

\subsection{The Science Process Skills Learning Technique Meaningful}

Finding evidence of teacher success in shaping self-learning for children's science-based process skills is an indication that children are beginning to master these skills. Means learning means achievement. Learning means that children can develop their own science process skills and really understand what they are doing. The findings of this study are in line with Ausubel's theory that learning is meaningful when children are able to associate existing experiences with new experiences and that additional information is based on mastery of those skills. Examples include data from observations to make comparisons, predictions and inferences. Successful activities to this level have shown that science process skills have been mastered. It means teachers need to guide children to learn autonomously and to practice it as a learning routine.

The study also found that it was necessary to create a document or record as a guide for the child during the activity. The journal notes this observation should show directions in the form of science process skills. Teacher creativity in terms of pedagogical content, teaching aids (ABM) and in-class training documents serve as indicators of achievement of mastery of skills.

Implementation of teaching based on a play-by-learning approach and the findings of the findings are the study participants' choice in teaching and learning early science. In line with research by Ngah (2011) stated that playing can increase students' interest in learning Science. However the study participants agreed that the project approach was most effective in practicing science process skills. This is supported by a study (Fauziah, 2008; Romazila et al., 2018), which 
found that the Project Approach successfully captures students' active participation through fun and meaningful learning activities. However the project approach is not very popular in terms of implementation based on the lack of resources as a guide, unless the teacher is proactive in finding himself.

Science process skills are also practiced directly in the daily activities of children. Free playtime is a great time as children are free to explore activities. The role of the teacher is to design and provide a rich environment of activity and equipped with clear self-directed instruction and practice.

An important resource for engaging activities is mastery of science process skills, practicing science process skills as a routine and interesting resources. The beginning of science becomes interesting when teachers know how to practice the science process in direct and indirect teaching. Research by Che et al. (2016) shows that when learning situations become interesting, students' interest in science can be enhanced. Science process skills such as observing, comparing, measuring, classifying, predicting and communicating are fundamental that teachers need to know. The practice of practicing these skills on a regular basis will be a factor in teaching early science.

\section{Summary and Conclusion}

The findings show that content knowledge and teacher teaching significantly influence the effectiveness of applying science process skills in early science teaching. A deep mastery of the basic concepts of science process skills as well as a high level of knowledge of the early science curriculum can make teaching and learning of early science meaningful in the context of mastery of science process skills. Teaching planning in terms of choosing the right approach and setting the science process skills that you want to achieve in teaching are also factors in effective achievement of science process skills. The role of teachers is very important and is the catalyst for mastering the science process in teaching.

The implications of this study are to provide guidance on applying scientific process skills in teaching, interacting and managing the environment scientifically, authentically and comprehensively. This is practically proven as practiced by the study participants. The researcher proposes for further study on the application of science process skills involving respondents, methodologies and areas. The researcher also proposes the integration of Integrated Learning Modules and Application of Science Process skills in early science teaching.

\section{Acknowledgements}

This research was partially supported by grant received from the Faculty of Education, Universiti Kebangsaan Malaysia code PP-FPEND-2019.

\section{Conflicts of Interest}

The authors declare no conflicts of interest regarding the publication of this paper. 


\section{References}

Ali, N. (2014). Tinjauan Awal Interaksi Guru-kanak-kanak Dalam Pemupukan Kreatif Kanak-kanak Prasekolah (pp. 735-746). Proceeding of the Social Science Research. Sabah: ICCR.

Amirah Abdol Rahaman, M. J. (2018). Aplikasi Stem Dalam Pengajaran Dan Pemudahcaraan Di Sekolah Luar Bandar: Peluang Dan Cabaran. Bandung, Universities of Bandung: International Conference on Education and Regional Development.

Barnett, W. S. (2004). Better Teachers, Better Preschools: Student Achievement Linked to Teacher Qualifications. New Brunswick.

Bruner, J. (1966). Toward a Theory of Instruction. Cambridge, MA: Harvard.

Che, N., Che, A., Shaharim, S. A., \& Yahaya, A. (2016). Kesesuaian Persekitaran Pembelajaran, Interaksi Guru-Pelajar, Komitmen Belajar Dan Keselesaan Pembelajaran Dalam Kalangan Pelajar Biologi. Jurnal Pendidikan Sains \& Matematik Malaysia, 6, 101-120.

Chiam, H. K. (2003). Clear Link between Teachers and Truancy. The Star.

Chong, S., \& Cheah, H. M. (2009). A Value, Skill and Knowledge Framework for Initial Teacher Preparation Programmes. Australian Journal of Teacher Education, 34, 1-18. https://doi.org/10.14221/ajte.2009v34n3.1

Cobern, W., \& Loving, C. (2002). Investigation of Preservice Elementary Teacher's, Thinking about Science. Journal of Research in Science Teaching, 39, 1016-1031. https://doi.org/10.1002/tea.10052

Curriculum Development Division (2010).

Darling-Hammond, L., \& Baratz-Snowden, J. (2005). A Good Teacher in Every Classroom: Preparing the Highly Qualified Teachers Our Children Deserve (Vol. 4, pp. 114-132). Graduate School Education.

Fauziah, M. J. (2008). Kepentingan Aktiviti Bermain Di dalam Pendidikan Prasekolah. Kedah, Malaysia: Bidang Pendidikan, Kolej Sastera dan Sains, Universiti Utara Malaysia.

Hafizah, M., Abu Yazid, A. B., \& Salleh, A. (2019). The Socio-Emotional Development of Preschoolers: A Case Study. Konselor, 8, 1412-9760. https://doi.org/10.24036/0201981103975-0-00

Lilia, H. (2013). Syarahan Perdana Pendidikan Sains dan Pembangunan Masyarakat Berliterasi sains. Bangi: Universiti Kebangsaan Malaysia Bangi.

Morrison, K. (2012). Integrate Science and Arts Process Skills in The Early Childhood Curriculum. Dimension of the Early Childhood, 40, 31-39.

Ngah, N. H. (2011). Increasing Students' Interests in Learning Science in the Title "Animal Protection from Danger" Using (Game) Methods. Journal Action Research IPG Campus Dato Razali Ismail, 1, No. 2.

Piaget, J. (1970). The Science of Education and the Psychology of The Child. New York: Grossman Preschool Science Environment: What Is Available in a Preschool Classroom?

Romarzila, O., Zanaton, H. I., \& Sharifah, N. P. (2018). A Comprehensive 21st Century Child Development through Project Based Learning. Journal of Advanced Research in Dynamical \& Control Systems, 10, 1636-1642.

Santrock, J. W. (2011). Child Development. New York: McGraw-Hill International.

Sharifah, N. P., Romarzila, O., \& Rosniza, M. Z. (2012). Teachers' Knowledge, Skills and Attitudes towards the Implementation of Preschool Curricular Innovations. In Proceedings of the 5th International Conference on Educational Reform 2012 (ICER 
2012).

Stivers, J. B., \& Schudel, D. (2008). Dream-Makers Early Childhood: Cherishing Young Children's Creativity. Easton, PA: Crayola.

Subahan, T., Meerah, M., Lilia, H., \& Thiagarajan, N. (2010). Environmental Citizenship: What Level of Knowledge, Attitude, Skill and Participation the Students Own? Procedia-Social and Behavioral Sciences, 2, 5715-5719. https://doi.org/10.1016/j.sbspro.2010.03.933

Torrance, E. P. (1979). The Search for Satori and Creativity. Buffalo, NY: Bearly Limited.

Vygotsky, L. (1984). School Instruction and Mental Development.

Ward, J. R., \& Mc Cotter, S. S. (2004). Reflection as a Visible Outcome for Pre-Service. Teacher-Teaching's Teacher Education, 20, 243-257. https://doi.org/10.1016/j.tate.2004.02.004

Wilke, R. (1985). Mandating Preservice Environmental Education Teacher Teaching: The Wisconsin Experience. The Journal of Environmental Education, 17, 1-8. https://doi.org/10.1080/00958964.1985.9941392

Zurida, H. I., \& Hashimah, M. Y. (2004). Sikap dan Keyakinan Guru-guru Prasekolah Dalam Pengajaran Sains Awal. Prosiding Seminar Kebangsaan 2004 Pendidi kan Awal dan Pendidikan Khas kanak-kanak. 